\title{
A PARTIAL CHRONOLOGY
}

1715 Death of Louis XIV.

1715-1723 Period of the Regency.

1720 Collapse in France and England of the unsound financial schemes known as the "Mississippi bubble" and the "South Sea bubble."

1721 Treaty of Nystadt signed by Sweden and Russia. Montesquieu's Persian Letters.

1723-1774 Reign of Louis XV.

1731 First version of Manon Lescaut.

1733-1735 War of Polish Succession.

1734 Voltaire's Letters on the English and Montesquieu's The Greatness of the Romans and Their Decline.

1740-1786 The reign of Frederick II (the Great) of Prussia.

1740-1780 The reign of Maria Theresa of Austria.

1740-1748 War of Austrian Succession.

1748 Hume's Inquiry Concerning Human Understanding and Montesquieu's The Spirit of the Laws.

1751 Appearance of the first volumes of Diderot's Encyclopedia.

1754 Diderot's On the Interpretation of Nature.

1756 Convention of Westminster signed by Britain and Prussia. Treaty of Versailles signed by France and Austria.

1756-1763 Seven Years War. 
1758 Quesnay's Economic Table.

1759 Voltaire's Candide.

1762 Rousseau's The Social Contract and Emile.

1762-1796 The reign of Catherine II (the Great) of Russia.

1763 Peace of Paris signed by Britain, France, and Spain. Treaty of Hubertusburg signed by Prussia and Austria.

1767 Lessing's Hamburg Dramaturgy and Minna von Barnhelm.

1772 First partition of Poland by Prussia, Austria, and Russia. Lessing's Emilia Galotti.

1774 Accession of Louis XVI. Fall of Maupeou and recall of the parlements. Treaty of KutchukKainardji signed by Russia and Turkey. Pugachev's uprising in Russia. Goethe's Werther.

1776 American Declaration of Independence. Adam Smith's The Wealth of Nations.

1778 Death of Voltaire and Rousseau.

1780-1790 The reign of Joseph II of Austria.

1781 Kant's Critique of Pure Reason.

1784 First books of Herder's Ideas on a Philosophy of History of Mankind and Schiller's Love and Intrigue.

1788 Kant's Critique of Practical Reason.

1789 Calling of the Estates General in France and proclamation of the Declaration of the Rights of Man and of the Citizen. 